\title{
シャドウイメージングを用いたエマルジョン燃料噴霧火炎における 二次微粒化現象の可視化
}

Visualization of secondary atomization in emulsified fuel spray flame by magnified shadow imaging

\author{
○正 渡部 弘達（東工大院） \\ 山晅 拓馬（大阪大院） \\ 正 赤松 史光（大阪大院）
}

\author{
東海林 豊（東工大院） \\ 正 林 \\ 正 岡崎
}

Hirotatsu Watanabe, Yutaka Shoji, Takuma Yamagaki, Jun Hayashi, Fumiteru Akamatsu and Ken Okazaki

Tokyo Institute of Technology, 2-12-1 Ookayama Meguro-ku, Tokyo 152-8550

Osaka University, 2-1 Yamadaoka Suita-shi, Osaka 565-0871

\begin{abstract}
Secondary atomization of emulsified fuel in spray flame was visualized by magnified shadow imaging. An emulsified fuel spray was injected into a flame stabilized in a laminar counterflow field. Direct photography of the flame using a color high-speed video camera and magnified shadow imaging of spray droplets using a monochrome high-speed video camera were used. As a result, "bright spots" were observed in spray flame of the emulsified fuel, whereas it was rarely observed in spray flame of $n$-dodecane. Observations indicated that the droplet flame rapidly expanded. This expansion was linked to secondary atomization such as puffing and micro-explosion, which were visualized by magnified shadow imaging.
\end{abstract}

Key Words: Emulsified fuel, Secondary atomization, Flame, Micro-explosion, Puffing, High-speed photography

\section{1.はじめに}

噴霧燃焼における微粒化特性の大幅向上は重要である。 水エマルジョン燃料滴を版熱すると, Fig. 1に示すような,

ミクロ爆発が発生し，微粒化特性が大幅に向上することが 知られている。仮にすべての噴霧滴が，噴霧後，すみやか にミクロ爆発を起こしたならば，ガス燃焼並みのクリーン な噴霧燃焼が実現できる可能性がある.既往の研究として, 液滴径が $1 \mathrm{~mm}$ 程度の単一液滴を使用した実験は数多く行 われているが(1)，得りれた知見が粒径 $50 \mu \mathrm{m}$ 程度の噴霧滴 に適用できるかゔうか検討の余地があった。近年，噴霧を 対象とした二次微粒化の研究が行むれているが，火炎内に おけるュマルジョン燃料噴霧滴の挙動は未解明な点が多い, 本研究では, シャドウイメージングによりエマルジョン然 料噴霧火炎に扩ける二次微粒化現象在可祝化し，噴霧滴の 挙動を明らかにする。

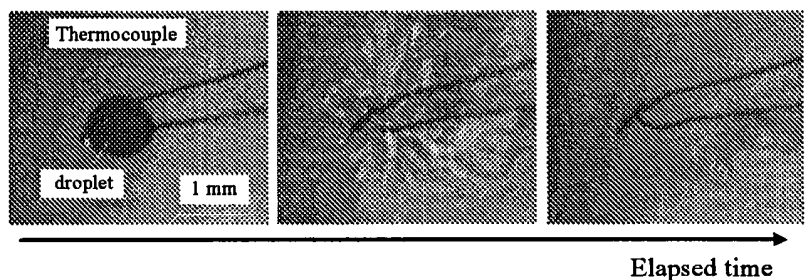

Fig. 1 The series of photographs of an emulsified fuel droplet in an electric furnace (1000 fps) ${ }^{(1)}$

\section{2. 実験}

水エマルジョン燃料 $(250 \mathrm{ml})$ は， $n$-ドラ゙カンに水を 10 vol\%を界面活性剂のソルビタンモ)オレート（エマゾール O-10V, HLB 值 $=4.3$, 花王)を 0.75 vol\%加え, ホモジナ イザーで 20 分間かく汼混合して調整した.

Fig. 1 に使用した観察シスデムの概要と対向流バーナを 示す. 噴霧滴の挙動を観察する場合は，バックライトによ り形成される噴霧の影をモノクロハイスビードカメラで捉 えるシャドウイメージングを用いた。この場合，モノクロ ハイスピードカメラを使用し，フレームレートは 180,064 fps, 有効画素数は $128 \times 128$, 解像度は $12.0 \mu \mathrm{m} /$ pixel 亡した. 噴霧火炎の䚀察を行う場合は，カラーハイスピードカメラ

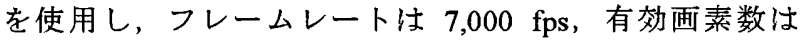
$256 \times 256$, 解像度は $20.0 \mu \mathrm{m} / \mathrm{pixel}$ とした．対向流バーナの 噴霧器には，超音波噴霧ノズルを使用した。実験の際は， ト下ボートからの気相流速を $0.91 \mathrm{~ms}^{-1}$ と一定とし, 伸長率 $60.4 \mathrm{~s}^{-1}$ の対向流場を形成した. 予混合噴霧中の液体燃料の 当量比を, エマルジョン燃料の場合は $0.032, n$-ドデカンの 場合は 0.028 と, 希薄条件に設定した。侧ボートにより 当量比 $0.6 の \mathrm{CH}_{4} / \mathrm{air}$ 予混合気を供給し, ガス火炎を安定化 させた後, 上側ポートから予混合噴雺を供給する。 ガス火 炎を形成することで，高温場に突入する噴靎を模擬してお り, また, 当量比 0.03 程度の噴霧火炎を保持することが可 能になる。本研究では, 噴霧滴の挙動を観察するため, 対 向流バー十の詳細は参考文献(2)を参考されたい，エマルジ ヨン燃料噴霧後の油中水滴径の平均径は, $5.1 \mu \mathrm{m}$ であった。

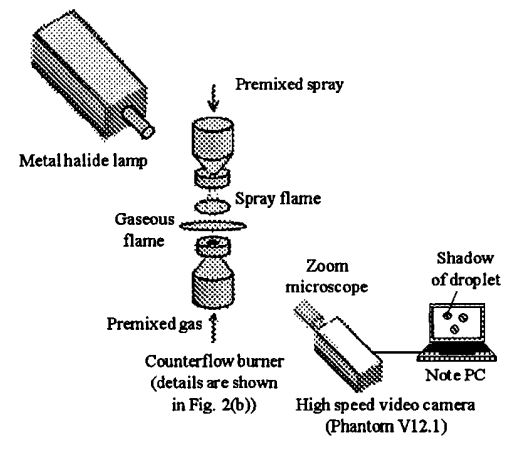

(a) Setup for visualizing droplets in spray flame

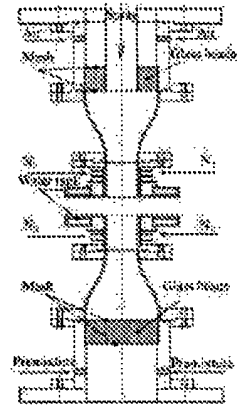

(b) Laminar counter flow burner
Fig. 2 Setup for visualizing droplets in spray flame

Fig. 3 に刘向流場に形成される噴霧火炎とガス火炎の位 置を示寸、噴霧滴の举動を観察寸る場合は, 中心軸上に 3 $\mathrm{mm}$ 間隔で撮影し、ミクロ爆発およびパッフィング（蒸気 吹き出し）を観察した。 


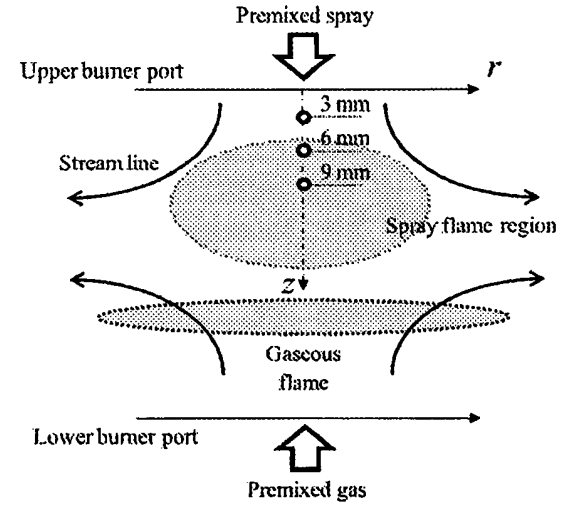

Fig. 3 Schematic diagram of flame and measuring points

\section{3. 結果と考察}

Fig. 4 に, $\boldsymbol{n}$-ドラ゙カン噴雼火炎とエマルジョン燃料噴霧火 炎の高速度写真を示す. $n$-ドデカンの場合, 上流部で, 単 滴もしくは油滴群の燃焼が起こっておう，青炎が観察され た。その後，輝炎が形成されている，一方，エマルジョン 燃料の噴霧火炎では，これらの火炎に加えて，周囲よりも 著しく輝度が大きいスポットが観察された。
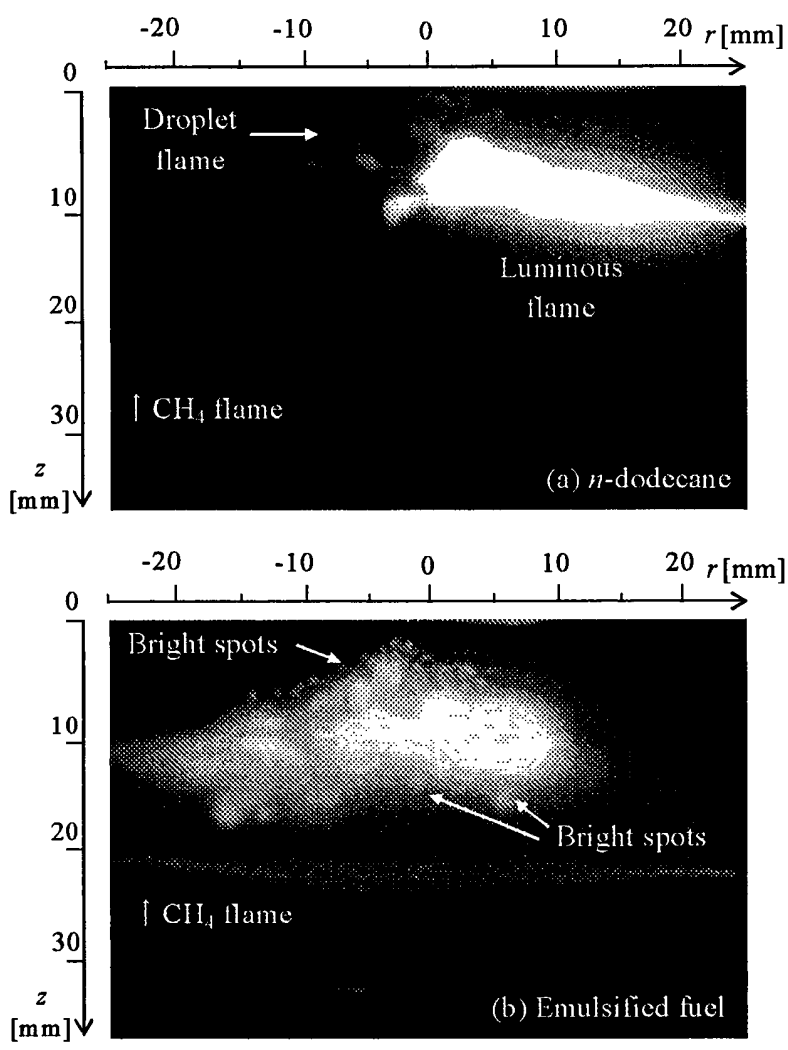

Fig. 4 Instantaneous photographs of spray flame (7000 fps)

Fig. 5 に，画像処理により噴霧滴の火炎をより強調した 火炎画像を示寸. 前述の通り, エマルジョン噴霧火炎では, さまざまな箇所で Bright spotsが観察されており，高速度冚 真においては，Bright spotが形成され，消减する現象が多 数観察された.

Fig. $6 に z=9 \mathrm{~mm}$ の位㯰に打いて撮影されたエマルジョ ン噴霧滴の高速度写真示す。 $30 \mu \mathrm{m}$ 程度の噴霧滴が，バ ッフィングを繰り返し，液滴が大きく変形している，その
後，液滴が 4 つに分裂しており，ミクロ爆発が発生してい る. 19/180064 s ( て，複数の二次微柆化が発生し，二次微柆化により，燃料 蒸気の拡散が促進され，その結果，エマルジョン噴霧火炎 に㧍いて，Fig. 3(b)，4(b)で見られた Bright spots が形成され たと考えられる。
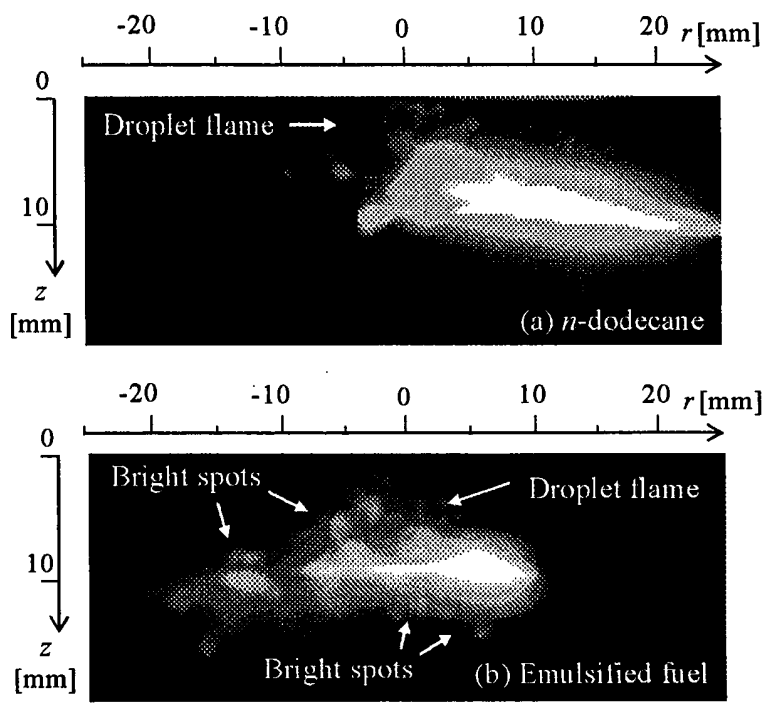

Fig. 5 Photographs of spray flame after image processing
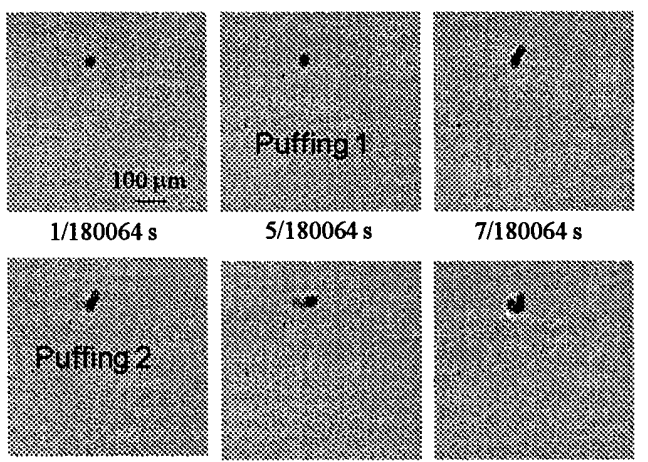

8/180064s
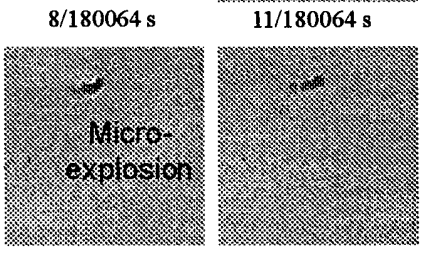

$14 / 180064 \mathrm{~s}$

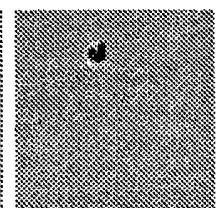

9/180064 s

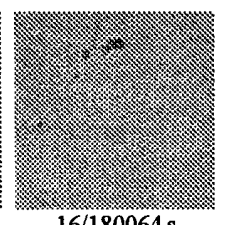

$16 / 180064 \mathrm{~s}$

Fig. 6 The series of photograph of spray droplet $(z=9 \mathrm{~mm})$

4.まとめ

エマルジョン燃料噴霧火炎に㧍いて, $n$-ドデカン噴霧火 炎では見られない Bright spot が多数観察された。シャドウ イメージングにより噴霧滴の挙動を観察すると，エマルジ ヨン燃料嗔霧では，短い時間スケールにおいて複数の二次 微粒化が発生しており，燃料蒸気の拡散が促進されること が示された。

\section{参考文献}

(1) Watanabe, H. et al., Int. J. Heat Mass Transfer, 52 (2009), 3676

(2) Hayashi, J. et al., Combust. Flame, 158 (2011), 2559 